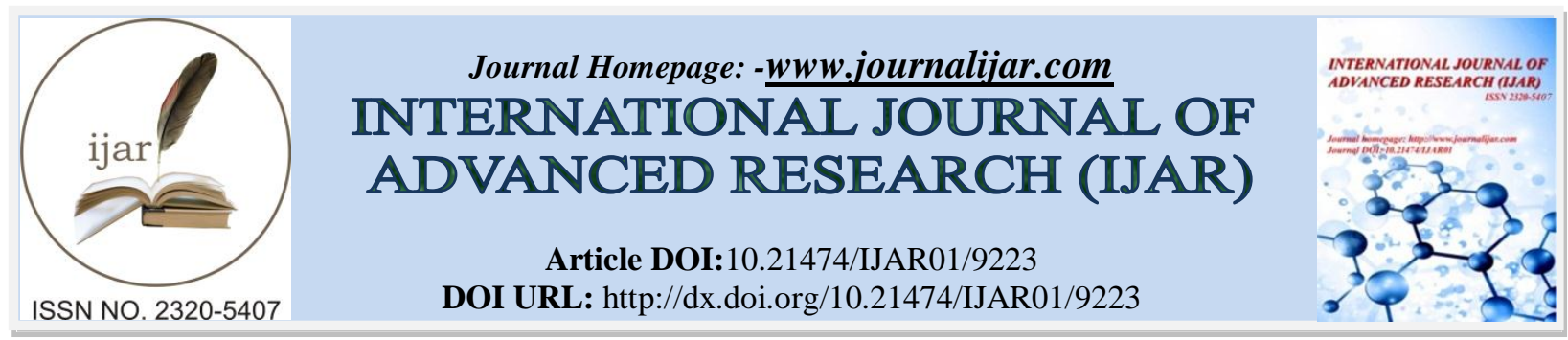

RESEARCH ARTICLE

\title{
EFFECTIVENESS OF TEXTBOOKS BASED ON PROCESS IMAGE IN EXCRETION SYSTEMS MATERIALS ON STUDENT'S HIGHER ORDER THINKING SKILLS (HOTS).
}

Nizia Utari Fihidayat, Indrawati, Jekti Prihatin and Sutarto.

Department of Science Education Magister, University of Jember, Jember, Indonesia 68121.

\section{Manuscript Info}

Manuscript History

Received: 06 April 2019

Final Accepted: 08 May 2019

Published: June 2019

Key words:-

Textbooks, process images, excretion systems, higher-order thinking skills.

\begin{abstract}
The application materials in the form of textbooks are still the most basic requirement in the process of learning Biology. Biology is one of the sciences that has the characteristics of the scope of physiological processes and mechanisms in it so it is necessary to use images. Textbook-based on process image in biology learning requires analysis and evaluation skills called Higher Order Thinking Skills (HOTS). This study aimed to examine the effectiveness of the use of textbooks based on process images in the excretion system material process towards students' higher order thinking skills. The design applied for this research is Pretest-posttest design only, with two sessions in three different classes. Data analysis through the calculation of the value of higher order thinking skill (HOTS). Then, the values were analyzed using the Recognition method to find out the categories of higher-order thinking skills of students. The results of this study indicated three schools included in the categories both with consecutive values, 81.5 (Class A); 80.3 (Class B) and 80.5 (Class C).
\end{abstract}

Copy Right, IJAR, 2019,. All rights reserved.

\section{Introduction:-}

Textbooks are still common teaching materials used by teachers in the learning process (Chu, 2018). The use of printed textbooks $(56.5 \%)$ is more common than the digital version (Hales, 2016). Textbooks are also still the main need for improvement and support in student learning (Bennett et al., 2015), including in guiding students to apply student-centeredlearning processes. In Indonesia, the 2013 curriculum has been implemented which emphasizes student-centered learning and is no longer applies teacher-centered learning. Teacher-centered learning processes canlimit students from thinking creatively andindependently (Susbandya et al., 2018). This will also limit students' broad understanding of the concept of learning.

Understanding students' concepts can be optimized by applying meaningful learning. Creating meaningful learning through learning activities by reducingmemorization activities, so learning is more meaningful because students understand the concept by forming their own understanding (Wicaksono at al.,2017). The low understanding of students' concepts can be caused by the learning process given cannot connect material concepts with everyday life (Wicaksono et al.,2017). The use of printed books, in general, is still not able to train students' ability to understand concepts optimally (Chu, 2018). This is because textbooks, in general, are still dominated by verbal explanations or words and lack of images that can visualize processes related to the concept of Biology. 
Biology is a science that is closely related to the use of visualization of physiological processes in it (Busetal., 2018). Image visualization can make optimal illustrations in the brain (Howe et al., 2016). In this research, it was found that students felt happier learning to use printed books and felt more interested in learning by using printed books equipped with many images, with consecutive percentages are $94 \%$ and $83 \%(\mathrm{~N}=18)$. This shows that images can increase student interest in Biology subjects, including excretory system material.

In this research, it was found that $94 \%(\mathrm{~N}=18)$ students stated they had difficulty understanding the physiological concepts of the excretory system, for example, the process of forming urine, the molecules contained at each stage of the process of urine formation, sweating and bile formation. The processes that occur in the body are biologically characterized by organization, interaction, complex components, and dynamic processes (Assarafet al., 2011). The physiological processes that occur in the excretory system cannot be observed directly and are abstract.

Basically, the concepts in biology learning cannot be separated from images and interrelated processes. So, one form of innovation that can be done is to unite the linkages between images and processes. Process image as a series of images from the initial condition to the end in the form of objects, events, or phenomena, where one image with the next image has a difference, but differences in images are seen as sequence or sequence of conditions (Sutarto et al., 2018). Process image characteristics, which consist of several different images (size, shape, color, position), images arranged sequentially, interconnected, and describe certain processes (Harianto et al., 2017). Therefore, students can practice analyzing the relationship of each sequence of images that illustrates a concept.

Higher order thinking skills or known as HOTS is one of the characteristics of 21 st century learning with the ability to think that involves analysis, evaluation, and creation (Higgins, 2017). Higher order thinking skills (HOT) include logical abilities and reasoning, analysis, evaluation, creation, problem-solving, and decision making (Brookhart, 2010). Analytical ability is the ability ofan individual to show a causal relationship between parts, able to identify the causes and consequences of an event and provide arguments from a statement (Larsson, 2017). This is closely related to concept analysis and textbooks based on process images.

Textbooks based on processimageare presented through various illustrations of images, icons, symbols, shapes, and diagrams in such a way. The application of textbooks based on process image makes students learn the processes that occur according to the sequence of images, so as to train students' analytical skills (Yusmaret al., 2017). Images that are used to visualize a process will be processed in the brain so that it trains the power of illustration, especially the right hemisphere brain. The right hemisphere brain emphasizes things related to imagination, intuition, rhythm, music, images, creativity and emotions (Deco, 2017). This is closely related to the characteristics of textbooks based on process image.

Selection of the right media (easy to implement, communicative and informative) is a solution to overcome the problems that occur in the learning process (Shin et al.,2019), such as higher order thinking skills of students (HOTS). One of the media that can be used is textbooks based on process image to improve students' higher order thinking skills (HOTS), especially about the excretory system. Therefore, this study aims to analyze the effectiveness of textbooks based on process image on excretion system material for students' higher order thinking skills (HOTS).

\section{Research Method:-}

Type of research was developmental research $(\mathrm{R}$ and $\mathrm{D})$. This research included development research because it develops textbooks. The textbooks developedare textbooks based on process images on excretory system material for middle-classschools XI. This study uses the development adaptedfrom 4-D (Four D), including 4 steps, consisting of (1) define, (2) design, (3) development, and (4) disseminate. The research and development subjects of this study were class X IPA 1 Panji Public Higher School (Class A), Kapongan Public Higher School (Class B), and Asembagus Public Higher School (Class C), Situbondo, Indonesia 2018/2019 academic year. Research design using pretest-posttest design only. They measure the performance of higherorder thinking skills (HOTS) based on the test results. Measurement of student higherorderthinking skills (HOTS) was conducted twice in two sessions in each class.HOTS questions were given at each meeting and then the values are analyzed using HOTS scores. Then, HOTS scores were summed and calculatedin the form of values (formula 1), after which they were explained by category. The assessment of each aspect uses a Likert scale of 1 to 5 . The categories of each value for higher order thinking skills in Table 1. Then, the results of students' higher order thinking skills in Table 2. 


$$
V=\frac{\text { Sachieved score }}{\text { Total score }} \times 100
$$

Table 1:-Value category of Higher Order Thinking Skills (HOTS)

\begin{tabular}{|c|c|c|}
\hline No & Values & Category \\
\hline 1 & $20 \leq \mathrm{x}<36$ & Very Less \\
\hline 2 & $36 \leq \mathrm{x}<52$ & Less \\
\hline 3 & $52 \leq \mathrm{x}<68$ & Enough \\
\hline 4 & $68 \leq \mathrm{x}<84$ & Good \\
\hline 5 & $84 \leq \mathrm{x} \leq 100$ & Very Well \\
\hline
\end{tabular}

\section{Findings and Discussion:-}

This study aimed to analyze the effectiveness of textbooks thatneed to be further developed, especially textbooks based on process image in excretory system material for students' higherorderthinking skills (HOTS). Higher order thinking skills (HOTS) are measured from the HOTS Score. The average of higher order thinking of test result for each class (A, B, and C) are presented in Table 2. and Figure 1.

Table 2:- Results of the average value of student's higher order thinking (HOTS)

\begin{tabular}{|c|c|c|c|c|c|c|}
\hline \multirow[t]{2}{*}{ Session } & \multicolumn{2}{|c|}{ Class A } & \multicolumn{2}{|c|}{ Class B } & \multicolumn{2}{|c|}{ Class C } \\
\hline & $\mathbf{N}$ & Values & $\mathbf{N}$ & Values & $\mathbf{N}$ & Values \\
\hline 1 & \multirow[t]{2}{*}{32} & 81 & \multirow[t]{2}{*}{33} & 78 & \multirow[t]{2}{*}{30} & 80 \\
\hline 2 & & 82 & & 83 & & 81 \\
\hline Mean & \multicolumn{2}{|c|}{81.5} & \multicolumn{2}{|c|}{80.3} & \multicolumn{2}{|c|}{80.5} \\
\hline Category & \multicolumn{2}{|c|}{ Good } & \multicolumn{2}{|c|}{ Good } & \multicolumn{2}{|c|}{ Good } \\
\hline
\end{tabular}

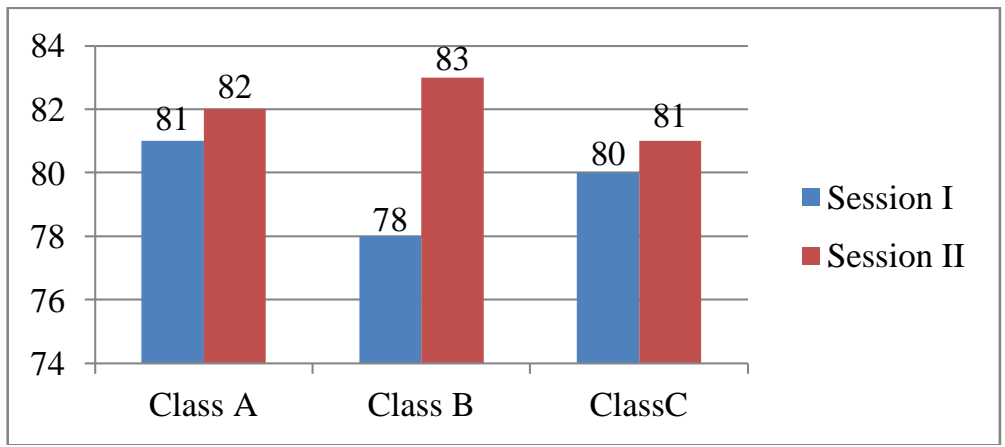

Figure 1:- The value of the student's Higher Order Thinking Skills (HOTS)

The information in Table. 2, and Figure 1 shows the value of higher order thinking skills in class A is 81.5; class B is 80.3 and class $\mathrm{C}$ is 80.5 . Values for class $\mathrm{A}, \mathrm{B}$, and $\mathrm{C}$ can be categorized as higher-order thinking skills (HOTS) students are "good".Furthermore, the frequency of the student's higher-order thinking skills categories in Table 3.

Table 3:-Results of percentage (\%) calculation ofstudent higher-order thinking skills (HOTS)

\begin{tabular}{|c|c|c|c|c|}
\hline \multirow[t]{2}{*}{ Values } & \multirow[t]{2}{*}{ Category } & \multicolumn{3}{|c|}{ Frequency of Student } \\
\hline & & $A(N=32)$ & B $(\mathbf{N}=33)$ & $\mathrm{C}(\mathrm{N}=30)$ \\
\hline $20 \leq x<36$ & Very less & 0 & 0 & 0 \\
\hline $36 \leq \mathrm{x}<52$ & Less & 0 & 0 & 0 \\
\hline $52 \leq x<68$ & Enough & 0 & 0 & 0 \\
\hline $68 \leq x<84$ & Good & 17 & 22 & 25 \\
\hline $84 \leq x \leq 100$ & Very good & 15 & 11 & 5 \\
\hline \multicolumn{2}{|c|}{ Percentage (\%) } & $\begin{array}{c}54 \%(\text { Good }) \\
46 \%(\text { Very good })\end{array}$ & $\begin{array}{c}67 \% \text { (Good) } \\
33 \% \text { (Very } \\
\text { good) }\end{array}$ & $\begin{array}{c}83 \%(\text { Good }) \\
17 \%(\text { Very good })\end{array}$ \\
\hline \multicolumn{2}{|c|}{ Standard deviation } & 0.01 & 0.01 & 0.01 \\
\hline
\end{tabular}


Based on Table 3, it can be seen that the category of student's higher order thinking skills about the excretory system is good with the percentage 54\% (A); 67\% (B) and 83\% (C). These results show an effective textbook based on process image for students' higher-order thinking skills in a good category.

\section{Discussion:-}

Based on Table 2, it can be seen that the higher order thinking skills of the students in classes A, B and C are good categories. This means that the textbook based on process image in excretion system material is effective for students' higher order thinking skills. That happens because of the availability of illustrative images with process images that train students' analytical skills. The process of visualizing concepts related to the excretion process is the main advantage of textbooks based on process image in excretory system material. Material illustrated byprocesses images can train analytical skills to understand the concept. Information presented through images also lasts longer in the brain than just words (Bransford et al., 2005; Rinne et al., 2011; Hardiman et al., 2014). Process images make students analyze the processes that occur in a series of images (Widita et al., 2018) so that the value of higher order thinking skills becomes good. Deco (2017) states that using different components of images, diagrams, writings, and colors can train the brain to analyze and think critically.

Good quality students can be created by teachers by choosing the right media that is by using visual media. Learning to use process image media can train students' analytical thinking skills. The images displayed in the lesson must be communicative and informative as a means of visualizing what you want to explain in the material. This makes students easier to understand than just using verbal sentences. According to Roetz \& Maritz (2016) that a person needs good creativity to develop analytical thinking skills, but the power of analysis can lead to different perspectives. This is an important requirement in the development of HOTS. Students can do the analysis process about the information by using a textbook based on process images.

Basically, the characteristics of process images also show a connection with the right hemisphere brain functions related to the imagination of image processing in the brain. The left hemisphere brain emphasizes things related to analysis, logic, and creation (Hamzelou, 2018: 1). The brain (cerebrum) is composed of two parts called the right hemisphere and the left hemisphere connectedto the corpus callosum (Champbell and Reece, 2008; Dzirasa, 2012; Luby, 2018). This is caused by mutual cooperation between the right and left hemispheres in carrying out their functions (Gulpinar, 2005; Gainotti, 2014). From the explanation above, it is important to maintain the work balance of the brain rather than the result of optimal thinking.

\section{Conclusion:-}

Based on the results and discussion, there is a change in the value of students' higher order thinking skills (HOTS) from meeting one to the meeting two when using textbooks based on process image in excretory systemmaterial in the learning process. So it can be concluded that the textbooks based on process image in excretion system material are effective for students' higher order thinking skills (HOTS). This can be seen from the average value of higher order thinking skills of students in the trials (A, B, and C) that meet the good category.

\section{References:-}

1. Assaraf, O.B., Dodick, J., and Tripto, J. (2011). Higher School Student's Understanding of the Human Body System. Res Sci Educ, (43):33-56.

2. Bennet, D., Amanda, J.R., Jennifer, C., Kimberly, C. (2015). Electronic Versus Traditional Print Textbooks: A Comparison Study on The Influence of University Student's Learning, (63): 259-266.

3. Bransford, J. D., Brown, A.L., and Cocking, R.R. (2005). How People Learn (Brain, Mind, Experience, and School). Washington: National Academy Press.

4. Brookhart, S.M. (2010). How To Assess Higher Order Thinking Skills in Your Classroom. Alexandria: ASCD.

5. Bus, A.G., Zsofia, K.T. (2018). How Picture in Picture Storybooks Young Children's Story Comprehension: An eye-tracking Experiment. Journal of Experimental Child Psychology, (174): 1-12.

6. Campbell, N . A., and Reece, J.B., B .L. (2008). Biology. Jakarta: Erlangga.

7. Chu, Y. (2018). Visualizing minority: Images of ethnic minority groups in Chinese Elementary Social Studies Textbooks. The Journal of Social Studies Research,42 (2): 135-147.

8. Deco, G., \& Kringelbach, M.L.. (2017). Hierarchy of Information Processing in the Brain: A Novel "Intrinsic Ignition" Framework. Neuron, 94 (5): 961-968. 
9. Dzirasa, K., \& Lisanby, S.H. (2012). How Does Deep Brain Stimulation Work?. Biological Psychiatry,72 (11): 892-894.

10. Gainotti, G. (2014). Why Are the Right and Left Hemisphere Conceptual Representations Different?. Behavioral Neurology: 1-10.

11. Gulpinar, M.A. (2005). The principles of Brain-Based Learning and Constructivist Models in Education. Educational Science: Theory \& Practice, 5(2): 299-306.

12. Hales, J.P. (2015). The Effects of Active Participation on Student Learning. The Journal of Educational Research, 2(4): 210-215.

13. Hamzelou, J. (2018). Bigger Brain Cells Work Better. New Scientist, 238 (3176).

14. Hardiman, M., Rinne, L., and Yarmolinskaya, J. (2015). The Effects of Art Integration on Long-term Memory of Academic Content. Mind, Brain, and Education, 8(3): 144-148.

15. Harianto, R., Harimukti, A., Sutarto, and Indrawati. (2017). Development of Module Based on Process Images for Learning of Circular Motion in Senior Higher School. Educational Steady StreamJournal, Jember University, 6(4): 17-22.

16. Higgins, S. (2017). Managing Higher-Order Thinking Skills. Managing Academic Libraries. 29-40.

17. Howe, A., Davies, D., Snape, D.J., Collier. C., Digby. R., Hay. P., (2016). Creative Learning Environments in Education- A Systemic Literatur Review. Thinking Skills and Creativity, 1(8): 80-91.

18. Larsson, K. 2017. Understanding and Teaching Critical Thinking - A New Approach. International Journal of Educational Research, (84): 32-44.

19. Luby, J.L. 2018. The Reciprocity of Brain and Behaviour. Journal of the American Academi of Child and Adolescent Psychiatry, 57 (6): 370-371.

20. Rinne, L., Gregory, E., Yarmolinskaya., and Hardiman, M. 2011. Why Arts Integration Improves Long-term Memory of Content. Mind, Brain, and Education, 5(2): 89-96.

21. Roets, L., and Maritz, J. 2016. Facilitating The Development of Higher-Order Thinking Skills (HOTS) of Novice Nursing Postgraduates in Africa, (16).

22. Shin, J., Badgwell, T.A., Liu, K.H., \& Lee, J. H. (2019). Reinforcement Learning - Overview of Recent Progress and Implications for Process Control. Computers \& Chemical Engineering.

23. Sutarto, Indrawati, Wicaksono, I., 2018. The Role of Picture Proses (PP) on Senior Higher School Students' Collision Concept Learning Activities and Multi-representation Ability. International Conference on Science Education (IcoSEd), 1(1): 1-6

24. Susbandya, D., Prihatin, J., Wahyuni, D., Sutarto, Indrawati. 2018. Enhancing Student's Retention of Knowledge By Using Digestive System Textbook Based on Process Images. International Journal of Advanced Research (IJAR), 6(6): 939-943.

25. Wicaksono, I., Wasis, Mandlazim. 2017. The Effectiveness of Virtual Science Teaching Model (VS-TM) to Improve Student's Scientific Creativity and Concept Mastery on Senior Higher School Physic Subject. Journal of Baltic Science Education, 16 (4):549-561.

26. Widita, E. L., Prihatin, J., Mudakir, I., Sutarto, Indrawati. 2018. The appliance of Textbook Basic on Process Images of Human Respiratory System Against Higher School Student's Critical Thinking Ability. International Journal of Advanced Engineering Research and Science (IJAERS),5(6): 191-194.

27. Yusmar, F., Susbandya, D., Widita, E. V., Maghfiroh, L., Prihatin, J., and Sutarto. 2017. A Concept: Enhancing Biology Learning Quality by Using Process Image. Educational Steady Stream Journal, Jember University, 6 (2):1-11. 